\title{
Role of Microglia in Neurotrauma
}

\author{
David J. Loane* and Kimberly R. Byrnes ${ }^{\dagger}$ \\ *Department of Anesthesiology \& Center for Shock, Trauma and Anesthesiology Research (STAR), National Study Center for \\ Trauma and EMS, University of Maryland School of Medicine, Baltimore, Maryland 21201; and Department of Anatomy, \\ Physiology and Genetics, Uniformed Services University of the Health Sciences, Bethesda, Maryland 20814
}

\begin{abstract}
Summary: Microglia are the primary mediators of the immune defense system of the CNS and are integral to the subsequent inflammatory response. The role of microglia in the injured CNS is under scrutiny, as research has begun to fully explore how postinjury inflammation contributes to secondary damage and recovery of function. Whether microglia are good or bad is under debate, with strong support for a dual role or differential activation of microglia. Microglia release a number of factors that modulate secondary injury and recovery after injury, including pro- and antiinflammatory cytokines, chemokines, nitric oxide, prosta-
\end{abstract}

glandins, growth factors, and superoxide species. Here we review experimental work on the complex and varied responses of microglia in terms of both detrimental and beneficial effects. Addressed in addition are the effects of microglial activation in two examples of CNS injury: spinal cord and traumatic brain injury. Microglial activation is integral to the response of CNS tissue to injury. In that light, future research is needed to focus on clarifying the signals and mechanisms by which microglia can be guided to promote optimal functional recovery. Key Words: Microglia, spinal cord injury, traumatic brain injury, inflammation.

\section{INTRODUCTION}

The role of microglia in the injured CNS is under scrutiny, as research has begun to determine how microgliamediated inflammation contributes to secondary injury and recovery of function following trauma. Whether microglial response to injury is good or bad is under debate, with strong support for a dual role and differential activation.

Microglia, which were first described by del Rio-Hortega ${ }^{1}$ in the early part of the 20th century, represent 10 $20 \%$ of the total cell population in the adult CNS. ${ }^{2}$ These cells are the resident immune cells of the CNS, belonging to the mononuclear phagocyte lineage, and are the primary mediators of the brain's innate immune response to infection, injury, and disease. It is commonly believed that these cells migrate into the CNS during development, and may continue to invade over the course of life, particularly after injury or insult. ${ }^{3}$

This review will explore the current research on microglial responses to CNS injury. The argument for a positive versus negative role of microglia will also be discussed. Two models of CNS injury, brain and spinal cord trauma, will be used to exemplify these responses in vivo. A large

Address correspondence and reprint requests to: Kimberly R. Byrnes, Ph.D., Room B2048, Department of Anatomy, Physiology and Genetics, Uniformed Services University of the Health Sciences, 4301 Jones Bridge Road, Bethesda, MD 20814. E-mail: kbyrnes@ usuhs.mil. variety of CNS injury models have been used in investigating microglial and inflammatory responses to CNS injury, and microglial responses vary depending on the injury model used and the severity of the injury inflicted. Data from brain and spinal cord trauma models, in which direct mechanical forces are applied to the CNS, were chosen in this review to reflect both the similarities and differences in responses, and to show the generality that one can expect from microglia in vivo (FIG. 1). Reviews of microglial responses in other models of CNS injury and disease, including stroke and ischemia, ${ }^{4}$ infection, ${ }^{5}$ multiple sclerosis, ${ }^{6}$ and neurodegenerative diseases, ${ }^{7,8}$ should also be consulted for a fuller understanding of microglial activity.

\section{GENERAL RESPONSE OF MICROGLIA TO INJURY}

Microglia are dynamic cells, constantly surveying their microenvironment for noxious agents and injurious processes. ${ }^{9}$ They respond to extracellular signals and are responsible for clearing cellular debris and toxic substances by phagocytosis, thereby maintaining normal cellular homeostasis in the CNS. To detect potential harmful insults, microglia express a set of pattern recognition receptors that recognize small molecular motifs found on pathogens or factors associated with tissue damage. These highly conserved pattern recognition receptors detect exogenous 


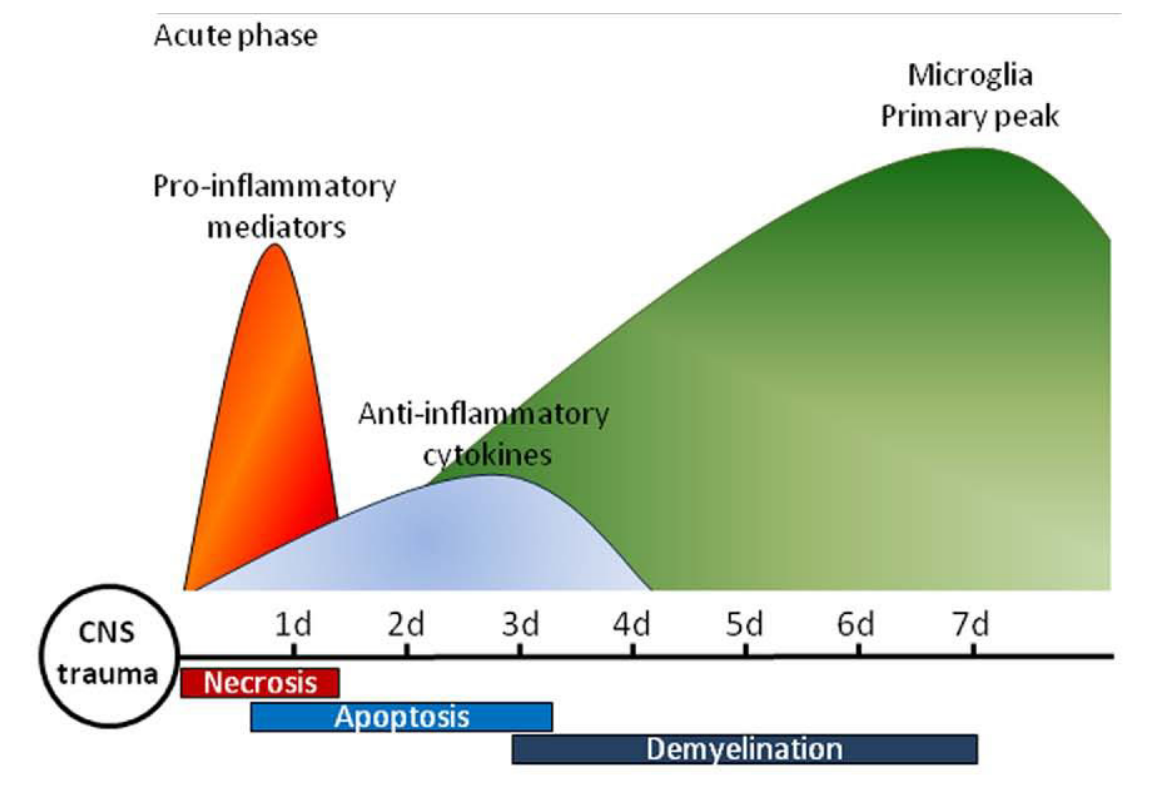

Chronic phase

MGactivation profile: $\quad M 1=M 2 \quad M 1>M 2$

$M 2>M 1(?)$

FIG. 1. Schematic of the microglial (MG) activation timeline after CNS injury, including inflammatory events and neurotoxic profiles in the acute and chronic phases. Also indicated are the proposed M1 and M2 microglial ratios over time.

pathogen-associated molecular patterns and endogenous danger-associated molecular patterns and enable microglia to identify and react to noxious stimuli and harmful events. ${ }^{10}$ Microglia also express receptors for a number of factors that are released by injured neurons, including ATP, glutamate, growth factors, and cytokines.

In the healthy adult brain, microglia are in a resting state and have a dendritic morphology with many processes. ${ }^{11}$ In response to injury, however, microglia undergo dramatic changes in cell morphology and behavior. For example, upon activation microglia contract their processes and transform from a ramified to an ameboid morphology resembling that of blood-borne macrophages, followed by proliferation and migration toward the site of injury. ${ }^{11}$ This convergence upon the site of injury is in response to ATP and other signals released by injured cells ${ }^{12,13}$; once there, microglia act as a barrier between the injured and healthy tissue. ${ }^{12}$

No markers are currently available that can distinguish cells in the CNS as resident activated microglia versus infiltrating macrophages. The two cell types have similar morphology, gene expression, and antigen presentation capabilities (for a review, see Streit et al. ${ }^{14}$ ). Microglia do, however, have significant differences from their bloodborne relatives, differences that are most likely related to their local microenvironment. For example, recent studies have suggested differences in protein expression profiles between macrophages and microglia, including differences in the level of CD45 expression ${ }^{15}, 16$ and galectin-3/MAC-2 expression. ${ }^{17}$ Furthermore, macrophages have twice as much proteolytic activity as microglia, and microglia have a more robust response to cytokine stimulation, in vitro. ${ }^{18,19}$
Preliminary proteomic analysis shows differences in 19 proteins, including superoxide dismutase, among microglia, bone marrow macrophages, and spleen macrophages ${ }^{18}$; in that study, however, the microglia and macrophages were isolated from different aged mice. Because age can affect macrophage activity, ${ }^{14,20}$ the reported differences in protein expression must be considered with caution.

\section{DETRIMENTAL RESPONSES OF ACTIVATED MICROGLIA}

The production of vast numbers of cytotoxic chemicals and their association with neuronal cell death has long contributed to the view that microglia play a detrimental role in the CNS (FIG. 2). A large number of studies have shown that microglia release proinflammatory mediators that contribute to neuronal dysfunction and cell death in response to injury and various immunological stimuli. $^{21-23}$ These neurotoxic substances include proinflammatory cytokines, chemokines, nitric oxide (NO), and superoxide free radicals that generate reactive oxygen species (ROS) and reactive nitrogen species (RNS).

Using the lipopolysaccharide (LPS) model of microglial activation, much research has shown that microglia can develop a neurotoxic phenotype. Lipopolysaccharide acts through either the Toll-like receptor 4 (TLR4) or $\mathrm{CD} 11 \mathrm{~b} / \mathrm{CD} 18$ (MAC1) receptor; both receptors induce a signal transduction cascade that modulates NF $\kappa \mathrm{B}$-mediated proinflammatory gene expression, potentially resulting in neuronal cell death. Knockout of the MAC1 receptor or MyD88 within the TLR4 pathway blocks microglia-mediated neuronal cell death. ${ }^{24,25}$ Activation 


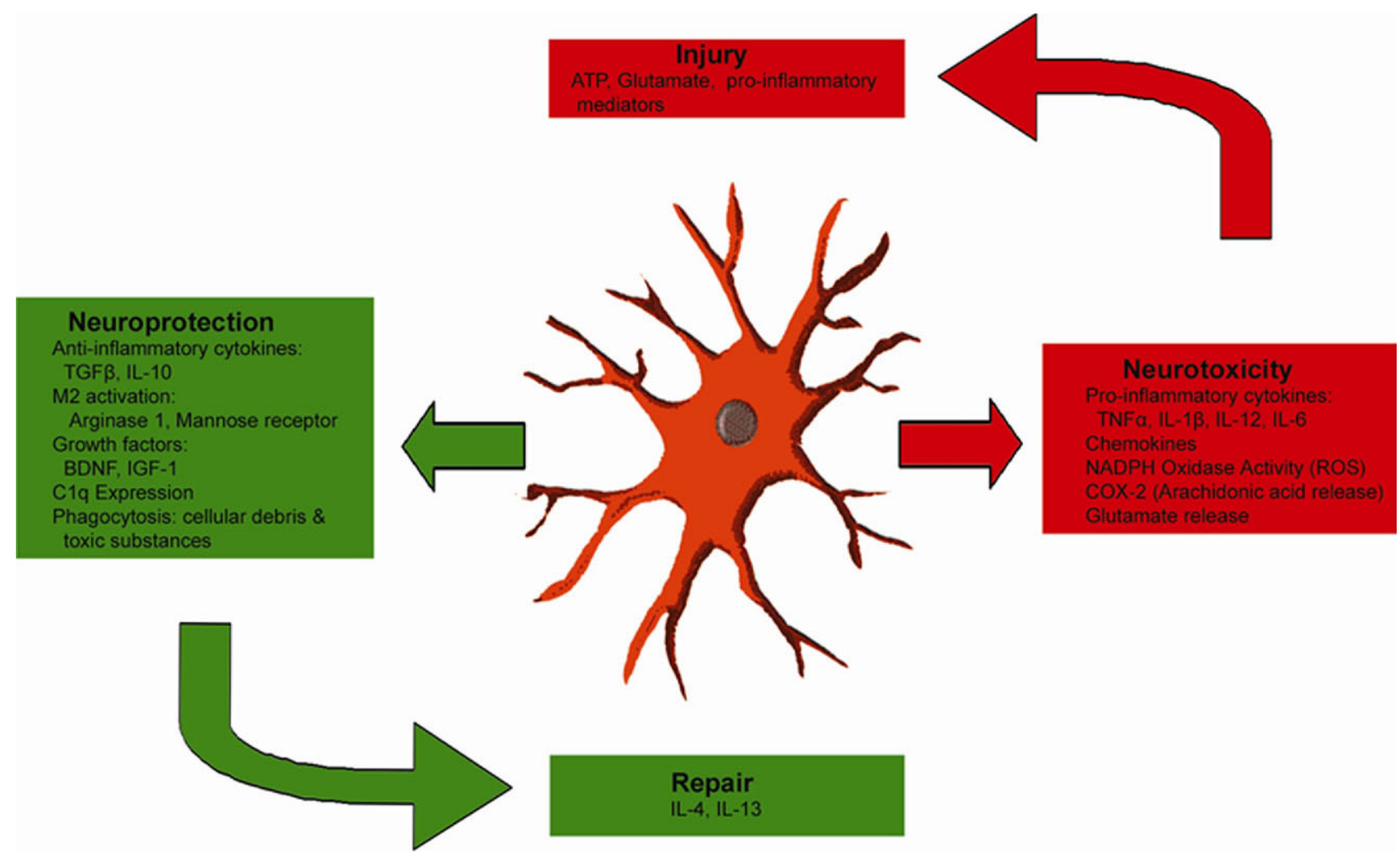

FIG. 2. Schematic of detrimental and beneficial effects of activated microglia. Red arrows indicate potential cytotoxic activities; green arrows indicate the pathways that may be protective.

of the MAC1 receptor also results in a phagocytic and toxic microglia phenotype, which is characterized by activation of NADPH oxidase and ROS production, ${ }^{10}$ as well as tumor necrosis factor- $\alpha(\mathrm{TNF}-\alpha)$ release. ${ }^{25}$

Numerous other factors can induce a neurotoxic phenotype in microglia. For example, exposure of microglia to myelin in a cell culture model to mimic myelin debris produced after injury resulted in the release of NO, TNF- $\alpha$, and glutamate, with subsequent neuronal death. ${ }^{26}$ The ATP and glutamate released by damaged neurons can also induce microglial activation, ${ }^{27}$ and abnormal protein aggregates, such as amyloid- $\beta(\mathrm{A} \beta)$ and $\alpha$-synuclein, activate microglia to secrete proinflammatory mediators such as TNF- $\alpha$, NO, and superoxide species. ${ }^{28-30}$ Exposure of cultured microglia to dying neurons results in the release of cytokines such as TNF- $\alpha$, interleukins IL-12 and IL-6, and RNS, as well as an increase in the expression of cell-surface antigens, CD40, major histocompatibility complex II (MHC-II), CD11b, and enzymes, such as inducible nitric oxide synthase (iNOS) and cyclooxygenase 2 (COX-2). ${ }^{31}$ Notably, media from microglia exposed to dying neurons induced subsequent neuronal death. ${ }^{31}$

The mechanisms by which microglia induce neuronal cell death are not fully understood, but several pathways have been shown to be involved. For example, microglial NADPH oxidase-related ROS release leads to increased internal zinc and potassium concentrations, resulting in neuronal apoptosis. ${ }^{32}$ The NADPH oxidase enzyme is activated by exposure of microglia to damaged neurons, ${ }^{33}$ neurotoxins such as rotenone ${ }^{34}$ and 1-methyl-4-phenyl1,2,3,6-tetrahydropyridine (MPTP), ${ }^{33,35} \mathrm{LPS}^{36,37} \mathrm{~A} \beta{ }^{29}$ and $\alpha$-synuclein. ${ }^{28}$ This multicomponent enzyme has two membrane components (p22 $2^{\text {phox }}$ and gp91 $\left.{ }^{\text {phox }}\right)$, as well as cytosolic components $\left(\mathrm{p} 47^{\text {phox }}, \mathrm{p} 67^{\text {phox }}\right.$, and $\left.\mathrm{p} 40^{\text {phox }}\right) .^{38}$ Stimulation results in the transport of the cytosolic components to the membrane to form the active enzyme complex and enables the production of extracellular ROS. NADPH oxidase is also thought to be a crucial component of microglial signaling, one that regulates the $\mathrm{NF} \kappa \mathrm{B}$ pathway and proinflammatory gene expression in these cells. ${ }^{37,39}$ NADPH oxidase knockout results in attenuated proinflammatory production and reduced microglia-mediated neurotoxicity. ${ }^{37}$

With age, resting microglia have been shown to take on a more activated phenotype, increasing expression of several receptors and markers, such as ionized calcium-binding adapter molecule 1 (Iba-1) ${ }^{40}$ and MHC-II. ${ }^{41,42}$ Aged microglia also exhibit hypertrophic and shortened processes that resemble an activated cellular morphology. ${ }^{40}$ Consistent with the view that activated microglia are the primary source of proinflammatory cytokines in the brain, several studies have demonstrated age-related increases in IL- $1 \beta$, IL-6, and TNF- $\alpha$ expression. ${ }^{4-45}$ Further, IL-1 $\beta$-positive microglia have been reported in the brains of aged individuals, ${ }^{46}$ and increased expression of 
IL-6 and TNF- $\alpha$ has been associated with age-related cortical atrophy in humans. ${ }^{47}$

Microglia are not only toxic to neurons but to other glial cells as well. Recently, it was shown that peroxynitrite, a short-lived potent oxidant and the reaction product of NO and superoxide, was the toxic microglial factor responsible for LPS-induced death of developing oligodendrocytes.$^{48}$ The presence of astrocytes alters the LPS-induced cell death mechanisms and shifts LPS-induced microglia-dependent toxicity of oligodendrocytes from a peroxynitrite-mediated mechanism to a TNF- $\alpha$ mediated mechanism. ${ }^{49}$

Short-term microglial activation is not considered to be detrimental (a concept that will be addressed in greater detail in subsequent sections). Chronic microglial activation, however, is considered to be the most damaging response of microglia to injury. ${ }^{50}$ For example, in the injured or diseased CNS, interactions between damaged neurons and dysregulated, hyperactivated microglia create a vicious self-propagating positive feedback loop that leads to uncontrolled, prolonged microglial activation and neuronal cell death that drives the chronic progression of neurodegeneration and disease. ${ }^{22}$

\section{BENEFICIAL RESPONSES OF MICROGLIAL ACTIVATION}

Short-term microglial activation may have beneficial effects (FIG. 2). As mentioned earlier, microglia phagocytose cellular debris and maintain normal cellular homeostasis, thereby preserving and protecting healthy tissue. ${ }^{51}$ Microglial phagocytosis is dependent upon C1q expression, among other things. ${ }^{52}$ Notably, C1q exposure has been shown to reduce LPS-induced cytokine expression, suggesting differences in level of activation between phagocytic and cytokine-expressing microglia. ${ }^{52}$ It has been suggested that the level of the inflammatory stimulus regulates the level of the microglial response. For example, $\mathrm{Li}$ et al $^{53}$ demonstrated that, although high levels of LPS $(>1 \mu \mathrm{g} / \mathrm{mL})$ induced proinflammatory cytokine expression and neurotoxicity, lower concentrations $(\leq 500 \mathrm{ng} / \mathrm{mL})$ increased neuronal cell viability and promoted neurite extension.

In recent years, a new classification of microglia has entered the literature. Described as an alternatively activated subset of microglia (M2), these cells have markers that can differentiate them from classically activated microglia (M1). ${ }^{54,55}$ The M2 microglia are typically considered to be less inflammatory than M1 microglia; they are characterized by reduced NO production and increased anti-inflammatory cytokine production. The M2 microglia express specific antigens such those to arginase 1 , mannose receptor, found in inflammatory zone 1 (FIZZ1), and chitinase 3 -like 3 (YM1) ${ }^{56}$ and are involved in tissue repair, wound healing, and extracellular matrix remodeling. ${ }^{55}$ After injury or in vitro following exposure to IL-4 or IL-13, microglia develop this nontoxic M2 phenotype, resulting in extensive neurite elongation and outgrowth across inhibitory surfaces. ${ }^{54,57}$ Furthermore, microglia exposed to IL-4 also demonstrate reduced proinflammatory cytokine production (e.g., TNF- $\alpha$ and IL-1 $\beta$ ) and increased anti-inflammatory or growth promoting factor production..$^{56,58}$

Microglia produce a number of neuroprotective substances in response to injury, such as anti-inflammatory cytokines and neurotrophic factors, including nerve growth factor, transforming growth factor $\beta$ (TGF- $\beta$ ), IL-10, and IL-1 receptor antagonist (IL-1ra) ${ }^{59-62} \mathrm{Be}-$ cause of its ability to bind to IL-1 receptor (IL-1RI) without initiating signal transduction, ${ }^{63}$ IL-1ra plays a major role in counteracting the biological effects of IL$1 \beta$. Furthermore, both TGF- $\beta$ and IL-10 inhibit macrophage and microglia activation by downregulating the expression of molecules associated with antigen presentation and production of proinflammatory cytokines, chemokines, and nitric and oxygen free radicals. ${ }^{59,64,65}$ After exposure to 6-hydroxydopamine (6-OHDA), increase was observed in microglial production of brain-derived growth factor (BDNF), insulin-like growth factor 1 (IGF1), and TGF- $\beta 2,{ }^{66}$ which led to improved neuronal cell viability in this model. Exposure to hypoxic neurons induced the production of BDNF and glial-derived neurotrophic factor (GDNF) in microglia. ${ }^{67}$ Similarly, exposure of microglial cultures to conditioned media from NMDA- or AMPA-treated neurons resulted in increased release of IL-1ra and was neuroprotective in this excitotoxicity model. ${ }^{68}$

Microglia can interact with other cells of the CNS and have significant beneficial effects. Recent data reported by Roy et al. ${ }^{69}$ suggest that cell-to-cell contact between $\mathrm{T}$ lymphocytes (Th2 cells) previously exposed to CNS antigens and microglia promotes the expression of neurotrophins (e.g., BDNF) without inducing release of proinflammatory cytokines. In contrast, the Th1 lymphocyte subtype cells stimulate microglia to produce proinflammatory cytokines rather than neurotrophins, demonstrating that T-cell subsets are associated with differential effects on microglial activity and gene expression. Note, however, that microglia themselves inhibit the proliferation of $\mathrm{CD} 4^{+} \mathrm{T}$ cells. ${ }^{70}$ Furthermore, activated microglia recognize and phagocytose infiltrating neutrophils, thereby limiting neutrophilic damage to healthy tissue. ${ }^{71}$

\section{ROLE OF MICROGLIA IN SPINAL CORD INJURY}

Spinal cord injury (SCI) results from an initial, mechanical insult on spinal cord tissue and is followed by secondary biochemical changes that produce long-term dysfunction. This secondary injury includes delayed 
events, such as ischemia, lipid degradation, free radical formation, excitotoxicity, and protease release, ${ }^{72,73}$ leading to demyelination, axonal degeneration, neuronal death, cavitation, and glial scarring surrounding the area of the initial damage. ${ }^{74-77}$ Inflammation, including the activation of resident microglial cells, plays an important role in these secondary changes. ${ }^{73,78,79}$

Direct damage to neurons and surrounding cells results in the release of a number of intracellular components and changes in extracellular ion content, such as glutamate and ATP, to which microglia are particularly sensitive. ${ }^{2,80}$ For example, expression of microglial cytokine, ATP, CD4, and glutamate receptors are upregulated, as well as MHC class I and II antigens, leading to an improved ability of microglia to respond to signals at the site of injury. ${ }^{77,81-83}$ Proinflammatory cytokines and chemokines are also rapidly upregulated and likely contribute to microglial activation. TNF- $\alpha$, for example, is produced by neurons, astrocytes and microglia ${ }^{84-86}$ and is upregulated rapidly after SCI. ${ }^{87-89}$ TNF- $\alpha$ acts to initiate a number of downstream signal transduction pathways, such as the $\mathrm{NF} \kappa \mathrm{B}$ and MAPK systems, ${ }^{90}$ and may promote glutamate-induced neurotoxicity by impairing microglial uptake of extracellular glutamate..$^{91}$

Advances in molecular biology, including improvements in microarray technology, have enabled more detailed analyses of injury and cellular responses. Gene expression analyses of SCI have demonstrated a strong inflammatory component, with nearly 200 inflammatory-related genes upregulated after injury, including genes for COX2, iNOS, MnSOD, HSP70, IL-1 receptor, and IL- $1 \beta{ }^{92-95}$ Microgliarelated genes, specifically, have also been profiled after SCI, demonstrating a strong elevation of gene expression both acutely and chronically after insult. ${ }^{96}$

Macrophages and microglia together comprise the monocytic reaction in the injured spinal cord, and there is significant upregulation of bromodeoxyuridine incorporation in microglial cells within residual spinal cord tissue after SCI. ${ }^{97}$ Macrophages from the periphery and activated microglia appear in the spinal cord between 12 and 24 hours after injury, with maximal infiltration at 4-8 days after injury (FIG. 1) ${ }^{98,99}$ Recent data have revealed that there is also a secondary peak of microglia and macrophage presence in the spinal cord at 60 days, with continued elevation through 180 days after SCI. ${ }^{100}$ Activated microglia and macrophages demonstrate gene expression profiles that reflect an increase in phagocytosis, upregulation of antigenpresenting capabilities, and secretion of proinflammatory molecules, ROS, and RNS. ${ }^{101}$

A study using bone marrow chimeric rats has shown that microglia are responsible for much of the immune response at the lesion site within the first days after $\mathrm{SCI}$, as well as in rostral and caudal regions. ${ }^{102}$ Yang et al. ${ }^{103}$ also demonstrated that resident microglia, rather than infiltrating macrophages, are the primary source of the proinflammatory cytokines IL- $1 \beta$, IL-6, and TNF- $\alpha$ acutely after SCI. Moreover, at 14 and 28 days after injury there are areas of increased bloodspinal cord barrier permeability rostral and caudal to the lesion site that are associated with $\mathrm{OX}-42^{+}$microglia expression. ${ }^{104} \mathrm{~A}$ recent study by Shechter et al. ${ }^{105}$ demonstrated that ablation of circulating monocytes and macrophages while maintaining microglial viability impaired functional recovery, suggesting that microglia strongly contribute to the loss of function in the injured spinal cord.

Studies have shown that ROS, components of NADPH oxidase, and peroxynitrite are chronically upregulated after SCI. ${ }^{106}$ Many of these factors are cytotoxic, ${ }^{107-109}$ as described earlier, or can inhibit cellular proliferation or progenitor replenishment. ${ }^{110}$ Further, there is evidence that microglia can cause axonal retraction through direct interactions. $^{111}$

Nonetheless, a variety of microglia-related factors may also play a role in neuroprotection and axonal survival after SCI. For example, macrophages and activated microglia expressing the M2 phenotype (arginase 1 and mannose receptor positive) are expressed immediately after SCI to 14 days after injury, along with the IL-4 receptor, which is associated with the M2 phenotype. ${ }^{54}$ Expression of these M2 microglial factors may promote CNS repair while limiting secondary inflammatory-mediated injury. Further, research has shown that chondroitin sulfate proteoglycans, proteins expressed by astrocytes, can induce microglial expression of IGF-1. ${ }^{12}$

Microglia also increase phagocytic activity after SCI in an effort to eliminate cellular and myelin debris in the injured spinal cord. Upregulation of ED1, a lysosomal protein, is indicative of increased lysosomal bodies within a cell and is a marker for increased cellular phagocytosis, whereas increased ED1 expression is highly correlated with the ability of microglia to phagocytose targets. ${ }^{113}$ Microglia response factor (MRF) and galectin-3 are also upregulated and correlated with phagocytosis by microglia, as demonstrated by immunostaining for phagocytosis of myelin in response to axonal transection or SCI..$^{96,114,115}$

\section{ROLE OF MICROGLIA IN TRAUMATIC BRAIN INJURY}

Mechanical forces at the moment of traumatic brain injury (TBI) cause rapid tissue deformation, resulting in primary physical damage. ${ }^{116}$ The mechanisms involved in cell death and tissue loss following TBI are complex interactions between acute and delayed biochemical, molecular, and physiological events that collectively mediate widespread neurodegeneration and loss of neurolog- 
ical function. These secondary injury mechanisms include glutamate excitotoxicity, blood-brain barrier disruption, secondary hemorrhage and ischemia, mitochondrial dysfunction, apoptotic and necrotic cell death, and inflammation. ${ }^{117}$ Such secondary injury events begin within seconds to minutes after the primary insult and may continue for days, weeks, and months, progressively contributing to worsening neurological function.

One of the central inflammatory responses to brain injury is activation of microglia. ${ }^{118,119}$ After acute injury, microglia have been shown to react within a few hours with a migratory response toward the lesion site. In fact, elegant in vivo two-photon microscopy imaging studies of fluorescently labeled microglia in transgenic mice following laserinduced injury demonstrated rapid proliferation and movement of ramified microglial cells to the site of injury in response to extracellular ATP released by the injured tissue. ${ }^{12,120}$ The microglial processes then fused to form an area of containment between healthy and injured tissues, suggesting that microglia may represent the first line of defense following injury. ${ }^{12}$ In humans with TBI, microglial activation has been reported as early as 72 hours after
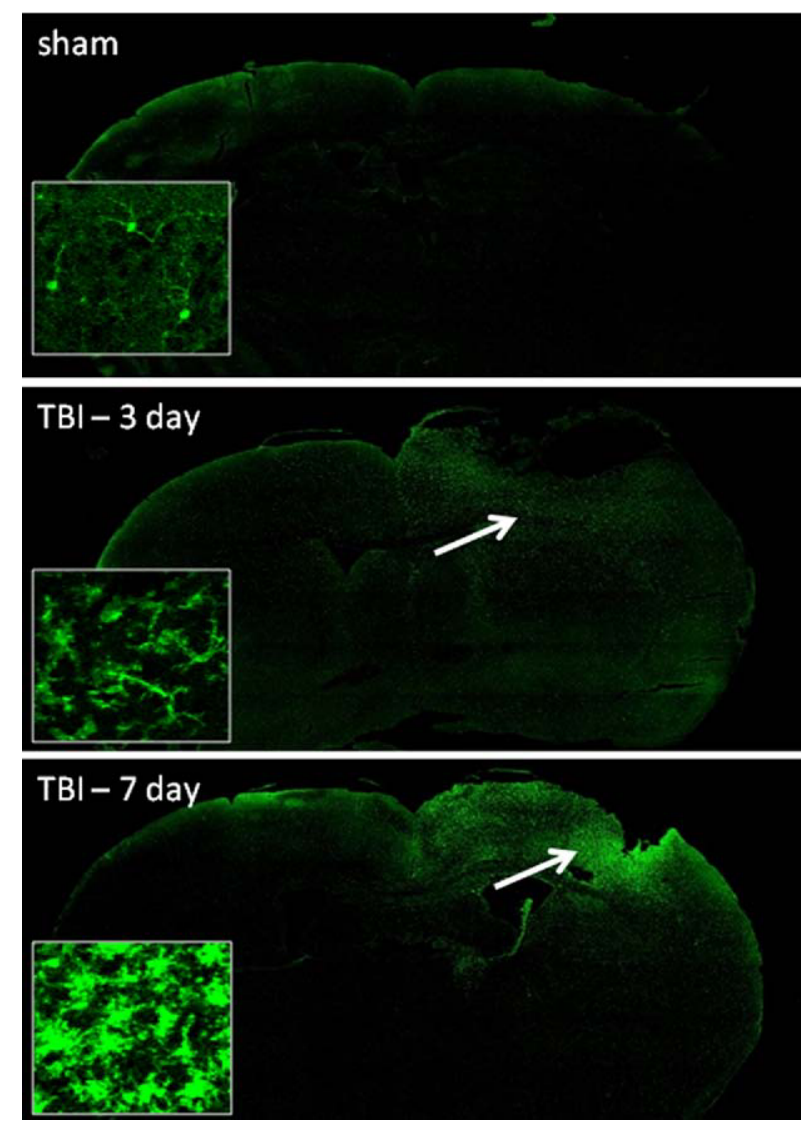

FIG. 3. Timecourse of microglial activation following experimental traumatic brain injury (TBI). Sham, 3 day TBI, and 7 day TBI brain samples were immunostained with anti-lba-1 to label activated microglia. Upon activation, microglia contract their processes and change from a ramified to an ameboid shape (inset), proliferate and migrate to the site of injury. injury, ${ }_{121}$ and it can remain elevated for months after injury. ${ }^{122,123}$ This activation profile is mirrored in rodent models of TBI (FIG. 3), and chronic microglial activation surrounding the lesion is evident weeks and months after the initial brain injury. ${ }^{124-126}$

Numerous gene profiling studies of TBI have been conducted using microarray technology, and genes related to inflammation are strongly upregulated in the acute phase after injury in both rats and mice. ${ }^{127-129}$ Follow-up studies on microglia-related genes and their temporospatial localization after TBI demonstrated that markers of activation (e.g., CD68, MHC-II), stress responses (e.g., p22 ${ }^{\text {phox }}$, heme oxygenase 1 ), and chemokine expression (e.g., CXCL10, CXCL6) were markedly increased after injury. ${ }^{130}$ Consistent with the early activation profile of microglia following injury, there is rapid upregulation of proinflammatory IL- $1 \beta$ mRNA within hours of experimental TBI. ${ }^{131-133}$ The damaging effects of IL- $1 \beta$ are mediated through IL-1RI, which is strongly expressed on microglia and neurons. ${ }^{131,134}$ This damage is not due to the cytokine itself, but rather to its effect on activating other proinflammatory pathways, such as TNF- $\alpha .{ }^{135}$ Inhibiting IL- $1 \beta$ in experimental models of TBI has been shown to be neuroprotective, improving functional recovery. ${ }^{131,132,136-138}$ In addition, TNF- $\alpha$ levels are elevated in both the serum and CSF of patients with severe TBI. ${ }^{139,140}$ TNF- $\alpha$ expression after experimental TBI is detectable after 1 hour, peaks between 3 to 8 hours, and returns to normal levels at 24 hours after injury. ${ }^{141-143}$ However, the role of TNF- $\alpha$ in the pathogenesis of TBI is somewhat controversial and complex in nature, with different functional outcomes in the acute and delayed phases after TBI. ${ }^{144,145}$

Anti-inflammatory cytokine levels are also modulated by TBI. In humans, IL-10 and TGF- $\beta$ levels are elevated acutely after injury, ${ }^{146,147}$ and experimental studies have shown that IL-10 has beneficial effects following trauma. ${ }^{148}$ For example, intravenous administration of IL-10 after experimental TBI in rats improved neurological recovery and significantly reduced TNF- $\alpha$ and IL- $1 \beta$ expression in the traumatized cortex and hippocampus. These neuroprotective effects may be a result of suppressed microglial activation, in that IL-10 treatment has been shown to decrease production of proinflammatory cytokines. ${ }^{149}$ Furthermore, injection of the anti-inflammatory cytokine TGF- $\beta 1$ after injury in rodents reduces lesion size ${ }^{150}$ improves function, and reduces iNOS production. ${ }^{151}$

It is well accepted that age influences microglial activation. ${ }^{46,152}$ Exacerbated microglial and astrocytic responses to injury are thus likely to be involved in enhanced susceptibility to and poor recovery from TBI in elderly patients. ${ }^{153,154}$ Recent studies have demonstrated that the microglial response to experimental TBI was exaggerated and prolonged in aged mice, relative to adult mice. ${ }^{155}$ These differences included increased microglial activation 
(CD11b and Iba-1 immunoreactivity) in the hippocampus of aged (21-24 months) versus adult (5-6 months) mice. This observation is consistent with reports of elevated microglial activation in the aged brain following injury such as facial nerve axotomy ${ }^{156}$ and cerebral ischemia. ${ }^{157}$ It has been proposed that, after injury, microglia in the aged brain are primed to respond more rapidly, produce more pronounced inflammatory responses, ${ }^{41}$ and proliferate more vigorously than microglia in the younger brain. ${ }^{156}$ Thus, hyperactivated and dysfunctional microglia in the aged hippocampus following TBI may contribute to enhanced neuronal loss in the hippocampus and worse neurological outcome in the elderly.

Compelling data from several epidemiological studies demonstrate that a history of TBI is one of the strongest risk factors for the development of Alzheimer's disease (AD) later in life. ${ }^{158-160}$ Further, it has been shown that $\mathrm{A} \beta$ plaques, a hallmark of $\mathrm{AD}$, may be found in patients within hours of TBI. ${ }^{161-163}$ Several possible pathophysiological mechanisms linking brain injury and $\mathrm{AD}$, such as the accumulation and clearance of $\mathrm{A} \beta$ peptides following TBI, have received much attention recently (for a review, see Johnson et al. ${ }^{164}$ ). However, chronic neuroinflammation is a common neuropathological feature of $\mathrm{TBI}$ and $\mathrm{AD}$, and chronic microglial activation may be a key causative factor. In $\mathrm{AD}, \mathrm{A} \beta$ is implicated in the pathology, both through direct toxicity to neurons ${ }^{165}$ and by potentiating neuronal damage by microglial activation. ${ }^{30}$ In patients with $\mathrm{AD}$, activated microglia cluster at sites of aggregated $\mathrm{A} \beta$ and penetrate the neuritic plaques. ${ }^{166,167}$ Furthermore, $A \beta$ is proinflammatory and activates microglia to release neurotoxic factors such as NO, TNF- $\alpha$, and superoxide. ${ }^{29,168}$ Following TBI, activated microglia surround the lesion and remain chronically activated for weeks and months after the initial brain trauma. ${ }^{125}$ Persistent long-term microglial activation was observed in the traumatized cortex 3 months after experimental brain injury and was associated with increased expression of proinflammatory cytokines, IL- $1 \beta$ and TNF- $\alpha .{ }^{169}$ In humans, long-term microglial activation and chronic inflammation may persist for many years in head injury survivors, ${ }^{123}$ with increased microglial activation detected in both parasagittal and hippocampal white matter in head-injured cases up to 16 years after injury. These long-term persistent inflammatory changes may cause post-traumatic neurodegeneration, which could form the basis of the cognitive decline that is often observed in long-term survivors of TBI.

\section{THERAPEUTIC IMPLICATIONS}

A number of therapeutic interventions have been developed that target microglia or microglia-related inflammation after traumatic CNS injury, such as minocycline, peroxisome proliferator-activated receptor $\gamma(\operatorname{PPAR} \gamma)$ agonists, and anti-inflammatory cytokines, among others. Minocycline is a second-generation tetracycline that is known to have anti-inflammatory properties independent of its antimicrobial activity. ${ }^{170}$ Studies have shown that minocycline inhibits microglia-mediated neurotoxicity ${ }^{171}$ and suppresses the production of several proinflammatory cytokines. ${ }^{172,173,174}$ In experimental models of TBI and SCI, minocycline treatment reduced tissue loss and improved functional recovery after injury. ${ }^{175,176-181}$ PPARs are ligand-activated transcription factors of the nuclear hormone receptor family ${ }^{182}$; activation of the PPAR $\gamma$ isoform has demonstrated significant anti-inflammatory effects, including attenuation of proinflammatory cytokine, iNOS, and COX2 expression. ${ }^{183}$ PPAR $\gamma$ agonists, such as rosiglitazone and pioglitazone, confer neuroprotection in models of acute CNS injury and neurodegeneration. ${ }^{184-188}$ In SCI and TBI models, anti-inflammatory cytokine administration, such as IL-10 and TGF- $\beta 1$, has been shown to improve functional outcome. ${ }^{148,189,150}$ The proinflammatory cytokine receptor antagonist IL-1 receptor antagonist (IL1ra) has also been found to have anti-inflammatory actions. In experimental models of TBI, neutralization of IL-1ra or IL- $1 \beta$ resulted in attenuated proinflammatory cytokine and chemokine production, reduced hippocampal damage, and improved neurological behavior after injury. ${ }^{131,132,136-138}$

Nonetheless, the dual role of microglia must be kept in mind. ${ }^{190,191}$ Although treatment to suppress microglial activity may reduce inflammation and improve neuronal survival or plasticity, ${ }^{192,193}$ it is possible that the beneficial effects of microglia may also be lost. For example, proinflammatory cytokines released by microglia are associated with increased nerve growth factor production by astrocytes. ${ }^{194}$ In addition, studies have shown that upregulation of microglial activity, by granulocyte-macrophage colony-stimulating factor (GM-CSF) injection or addition of activated microglia, can improve recovery after CNS injury. ${ }^{195,196}$ These studies indicate that much research remains to be done to fully understand the contribution of microglia to CNS injury recovery.

\section{SUMMARY}

Microglia are the primary mediators of the innate immune response to injury and disease in the CNS. These cells respond rapidly and specifically to the signals presented to them, and have the potential to play either a neuroprotective or a neurotoxic role after injury. Further understanding of the microglial cellular responses to traumatic injuries, including the initiating events, the signal transduction pathways involved, and the mediators produced, may facilitate identification of future therapies that promote the beneficial effects while preventing the detrimental and neurotoxic effects.

To date, a number of therapeutic interventions have 
been developed that target microglia or microglia-related inflammation after traumatic CNS injury. Although it is not necessary that these interventions act exclusively on microglia to elicit their beneficial effects, the evidence suggests that attenuating microglial activation and associated inflammation is a major mechanism of action of these therapies. In fact, several lines of research indicate that multipotential therapies that target microglial activation in addition to other secondary injury mechanisms, such as apoptotic cell death, are most likely to succeed in treating acute CNS injury and improving long-term functional outcome. ${ }^{197,198}$

In conclusion, it is clear that the microglial response to injury is complex and multifaceted. The influence of microglia on both propagation of secondary injury and continuing neuronal damage, as well as their influence on the beneficial, reparative, and wound-healing effects following injury, is beginning to be understood. These complex microglial responses need to be considered when investigating traumatic CNS injuries, and research must now focus on identifying the signals and mechanisms by which microglia can be guided to promote optimal recovery. In addition, a clear understanding of the influence of the various CNS injury models, severity of injury, and time on the microglial phenotypic responses would greatly enhance therapeutic approaches that target microglia. Finally, while the discovery of the M1 versus M2 microglial phenotypes is a considerable advance within the field, a detailed understanding of the role of the classic and alternatively activated microglial phenotypes, particularly with relation to chronic microglial responses to injury, is essential.

Acknowledgments: We thank Rainier Cabatbat for assistance with the illustrations, and we thank Dr. Bogdan Stoica for performing the immunofluorescence staining for Figure 3.

\section{REFERENCES}

1. del Rio-Hortega P. Microglia. In: Penfield W, editor. Cytology \& cellular pathology of the nervous system. New York: P.B. Hoeber, 1932:483-534.

2. Spranger M, Fontana A. Activation of microglia: a dangerous interlude in immune function in the brain. Neuroscientist 1996; 2:293-299.

3. Graeber MB, Streit WJ. Microglia: biology and pathology. Acta Neuropathol 2010;119:89-105.

4. Weinstein JR, Koerner IP, Möller T. Microglia in ischemic brain injury. Future Neurol 2010;5:227-246.

5. Yadav A, Collman RG. CNS inflammation and macrophage/ microglial biology associated with HIV-1 infection. J Neuroimmune Pharmacol 2009;4:430-447.

6. Jack C, Ruffini F, Bar-Or A, Antel JP. Microglia and multiple sclerosis. J Neurosci Res 2005;81:363-373.

7. Moisse K, Strong MJ. Innate immunity in amyotrophic lateral sclerosis. Biochim Biophys Acta 2006;1762:1083-1093.

8. Streit WJ, Conde JR, Fendrick SE, Flanary BE, Mariani CL. Role of microglia in the central nervous system's immune response. Neurol Res 2005;27:685-691.

9. Nimmerjahn A, Kirchhoff F, Helmchen F. Resting microglial cells are highly dynamic surveillants of brain parenchyma in vivo. Science 2005;308:1314-1318.
10. Block ML, Zecca L, Hong JS. Microglia-mediated neurotoxicity: uncovering the molecular mechanisms. Nat Rev Neurosci 2007; 8:57-69.

11. Vilhardt F. Microglia: phagocyte and glia cell. Int J Biochem Cell Biol 2005;37:17-21.

12. Davalos D, Grutzendler J, Yang G, et al. ATP mediates rapid microglial response to local brain injury in vivo. Nat Neurosci 2005;8:752-758.

13. Liu GJ, Nagarajah R, Banati RB, Bennett MR. Glutamate induces directed chemotaxis of microglia. Eur J Neurosci 2009;29:11081118.

14. Streit WJ, Walter SA, Pennell NA. Reactive microgliosis. Prog Neurobiol 1999;57:563-581.

15. Shaked I, Tchoresh D, Gersner R, et al. Protective autoimmunity: interferon- $\gamma$ enables microglia to remove glutamate without evoking inflammatory mediators. J Neurochem 2005;92:9971009.

16. Stirling DP, Yong VW. Dynamics of the inflammatory response after murine spinal cord injury revealed by flow cytometry. J Neurosci Res 2008;86:1944-1958.

17. Lalancette-Hébert M, Gowing G, Simard A, Weng YC, Kriz J. Selective ablation of proliferating microglial cells exacerbates ischemic injury in the brain. J Neurosci 2007;27:2596-2605.

18. Enose Y, Destache CJ, Mack AL, et al. Proteomic fingerprints distinguish microglia, bone marrow, and spleen macrophage populations. Glia 2005;51:161-172.

19. Albright AV, González-Scarano F. Microarray analysis of activated mixed glial (microglia) and monocyte-derived macrophage gene expression. J Neuroimmunol 2004;157:27-38.

20. Milligan CE, Levitt $P$, Cunningham TJ. Brain macrophages and microglia respond differently to lesions of the developing and adult visual system. J Comp Neurol 1991;314:136-146.

21. Block ML, Hong JS. Microglia and inflammation-mediated neurodegeneration: multiple triggers with a common mechanism. Prog Neurobiol 2005;76:77-98.

22. Gao HM, Hong JS. Why neurodegenerative diseases are progressive: uncontrolled inflammation drives disease progression. Trends Immunol 2008;29:357-365.

23. Griffin WS, Sheng JG, Royston MC, et al. Glial-neuronal interactions in Alzheimer's disease: the potential role of a 'cytokine cycle' in disease progression. Brain Pathol 1998;8:65-72.

24. Dean JM, Wang X, Kaindl AM, et al. Microglial MyD88 signaling regulates acute neuronal toxicity of LPS-stimulated microglia in vitro. Brain Behav Immun 2010;24:776-783.

25. Pei Z, Pang H, Qian L, et al. MAC1 mediates LPS-induced production of superoxide by microglia: the role of pattern recognition receptors in dopaminergic neurotoxicity. Glia 2007;55: $1362-1373$.

26. Pinteaux-Jones F, Sevastou IG, Fry VA, Heales S, Baker D, Pocock JM. Myelin-induced microglial neurotoxicity can be controlled by microglial metabotropic glutamate receptors. J Neurochem 2008;106:442-454.

27. Fang KM, Yang CS, Sun SH, Tzeng SF. Microglial phagocytosis attenuated by short-term exposure to exogenous ATP through P2X receptor action. J Neurochem 2009;111:1225-1237.

28. Zhang W, Wang T, Pei Z, et al. Aggregated $\alpha$-synuclein activates microglia: a process leading to disease progression in Parkinson's disease. FASEB J 2005;19:533-542.

29. Qin L, Liu Y, Cooper C, Liu B, Wilson B, Hong JS. Microglia enhance $\beta$-amyloid peptide-induced toxicity in cortical and mesencephalic neurons by producing reactive oxygen species. J Neurochem 2002;83:973-983.

30. Combs CK, Johnson DE, Karlo JC, Cannady SB, Landreth GE. Inflammatory mechanisms in Alzheimer's disease: inhibition of $\beta$-amyloid-stimulated proinflammatory responses and neurotoxicity by PPAR $\gamma$ agonists. J Neurosci 2000;20:558-567.

31. Pais TF, Figueiredo C, Peixoto R, Braz MH, Chatterjee S. Necrotic neurons enhance microglial neurotoxicity through induction of glutaminase by a MyD88-dependent pathway. J Neuroinflammation 2008;5:43.

32. Knoch ME, Hartnett KA, Hara H, Kandler K, Aizenman E. Microglia induce neurotoxicity via intraneuronal $\mathrm{Zn}^{2+}$ release and a $\mathrm{K}^{+}$current surge. Glia 2008;56:89-96. 
33. Gao HM, Liu B, Zhang W, Hong JS. Critical role of microglial NADPH oxidase-derived free radicals in the in vitro MPTP model of Parkinson's disease. FASEB J 2003;17:1954-1956.

34. Gao HM, Liu B, Hong JS. Critical role for microglial NADPH oxidase in rotenone-induced degeneration of dopaminergic neurons. J Neurosci 2003;23:6181-6187.

35. Wu DC, Teismann P, Tieu K, et al. NADPH oxidase mediates oxidative stress in the 1-methyl-4-phenyl-1,2,3,6-tetrahydropyridine model of Parkinson's disease. Proc Natl Acad Sci U S A 2003;100:6145-6150.

36. Loane DJ, Stoica BA, Pajoohesh-Ganji A, Byrnes KR, Faden AI. Activation of metabotropic glutamate receptor 5 modulates microglial reactivity and neurotoxicity by inhibiting NADPH oxidase. J Biol Chem 2009;284:15629-15639.

37. Qin L, Liu Y, Wang T, et al. NADPH oxidase mediates lipopolysaccharide-induced neurotoxicity and proinflammatory gene expression in activated microglia. J Biol Chem 2004;279:14151421.

38. DeLeo FR, Quinn MT. Assembly of the phagocyte NADPH oxidase: molecular interaction of oxidase proteins. J Leukoc Biol 1996;60:677-691

39. Pawate S, Shen Q, Fan F, Bhat NR. Redox regulation of glial inflammatory response to lipopolysaccharide and interferon $\gamma$. J Neurosci Res 2004;77:540-551.

40. Chung JY, Choi JH, Lee CH, et al. Comparison of ionized calcium-binding adapter molecule 1-immunoreactive microglia in the spinal cord between young adult and aged dogs. Neurochem Res 2010;35:620-627.

41. Godbout JP, Chen J, Abraham J, et al. Exaggerated neuroinflammation and sickness behavior in aged mice following activation of the peripheral innate immune system. FASEB J 2005;19: 1329-1331.

42. Lynch AM, Loane DJ, Minogue AM, et al. Eicosapentaenoic acid confers neuroprotection in the amyloid- $\beta$ challenged aged hippocampus. Neurobiol Aging 2007;28:845-855.

43. Gelinas DS, McLaurin J. PPAR- $\alpha$ expression inversely correlates with inflammatory cytokines IL- $1 \beta$ and TNF- $\alpha$ in aging rats. Neurochem Res 2005;30:1369-1375.

44. Godbout JP, Johnson RW. Interleukin-6 in the aging brain. J Neuroimmunol 2004;147:141-144.

45. Murray CA, Lynch MA. Dietary supplementation with vitamin E reverses the age-related deficit in long term potentiation in dentate gyrus. J Biol Chem 1998;273:12161-12168.

46. Conde JR, Streit WJ. Microglia in the aging brain. J Neuropathol Exp Neurol 2006;65:199-203.

47. Baune BT, Ponath G, Rothermundt M, Roesler A, Berger K. Association between cytokines and cerebral MRI changes in the aging brain. J Geriatr Psychiatry Neurol 2009;22:23-34.

48. Li J, Baud O, Vartanian T, Volpe JJ, Rosenberg PA. Peroxynitrite generated by inducible nitric oxide synthase and NADPH oxidase mediates microglial toxicity to oligodendrocytes. Proc Natl Acad Sci U S A 2005;102:9936-9941.

49. Li J, Ramenaden ER, Peng J, Koito H, Volpe JJ, Rosenberg PA. Tumor necrosis factor $\alpha$ mediates lipopolysaccharide-induced microglial toxicity to developing oligodendrocytes when astrocytes are present. J Neurosci 2008;28:5321-5330.

50. Block ML, Hong JS. Chronic microglial activation and progressive dopaminergic neurotoxicity. Biochem Soc Trans 2007;35: $1127-1132$.

51. Takahashi K, Rochford CD, Neumann H. Clearance of apoptotic neurons without inflammation by microglial triggering receptor expressed on myeloid cells-2. J Exp Med 2005;201:647-657.

52. Fraser DA, Pisalyaput K, Tenner AJ. C1q enhances microglial clearance of apoptotic neurons and neuronal blebs, and modulates subsequent inflammatory cytokine production. J Neurochem 2010;112:733-743.

53. Li L, Lu J, Tay SS, Moochhala SM, He BP. The function of microglia, either neuroprotection or neurotoxicity, is determined by the equilibrium among factors released from activated microglia in vitro. Brain Res 2007;1159:8-17.

54. Kigerl KA, Gensel JC, Ankeny DP, Alexander JK, Donnelly DJ, Popovich PG. Identification of two distinct macrophage subsets with divergent effects causing either neurotoxicity or regeneration in the injured mouse spinal cord. J Neurosci 2009;29:1343513444.

55. Colton CA. Heterogeneity of microglial activation in the innate immune response in the brain. J Neuroimmune Pharmacol 2009; 4:399-418.

56. Colton CA, Mott RT, Sharpe H, Xu Q, Van Nostrand WE, Vitek MP. Expression profiles for macrophage alternative activation genes in $\mathrm{AD}$ and in mouse models of $\mathrm{AD}$. J Neuroinflammation 2006;3:27.

57. Butovsky O, Talpalar AE, Ben-Yaakov K, Schwartz M. Activation of microglia by aggregated $\beta$-amyloid or lipopolysaccharide impairs MHC-II expression and renders them cytotoxic whereas IFN- $\gamma$ and IL-4 render them protective. Mol Cell Neurosci 2005; 29:381-393.

58. Lyons A, Griffin RJ, Costelloe CE, Clarke RM, Lynch MA. IL-4 attenuates the neuroinflammation induced by amyloid- $\beta$ in vivo and in vitro. J Neurochem 2007;101:771-781.

59. Aloisi F, De Simone R, Columba-Cabezas S, Levi G. Opposite effects of interferon- $\gamma$ and prostaglandin E2 on tumor necrosis factor and interleukin-10 production in microglia: a regulatory loop controlling microglia pro- and anti-inflammatory activities. J Neurosci Res 1999;56:571-580.

60. Liu JS, Amaral TD, Brosnan CF, Lee SC. IFNs are critical regulators of IL-1 receptor antagonist and IL-1 expression in human microglia. J Immunol 1998;161:1989-1996.

61. Kiefer R, Schweitzer T, Jung S, Toyka KV, Hartung HP. Sequential expression of transforming growth factor- $\beta 1$ by T-cells, macrophages, and microglia in rat spinal cord during autoimmune inflammation. J Neuropathol Exp Neurol 1998;57:385-395.

62. Elkabes S, DiCicco-Bloom EM, Black IB. Brain microglia/macrophages express neurotrophins that selectively regulate microglial proliferation and function. J Neurosci 1996;16:2508-2521.

63. Allan SM, Tyrrell PJ, Rothwell NJ. Interleukin-1 and neuronal injury. Nat Rev Immunol 2005;5:629-640.

64. O'Keefe GM, Nguyen VT, Benveniste EN. Class II transactivator and class II MHC gene expression in microglia: modulation by the cytokines TGF- $\beta$, IL-4, IL-13 and IL-10. Eur J Immunol 1999;29:1275-1285.

65. Frei K, Lins H, Schwerdel C, Fontana A. Antigen presentation in the central nervous system. The inhibitory effect of IL-10 on MHC class II expression and production of cytokines depends on the inducing signals and the type of cell analyzed. J Immunol 1994;152:2720-2728.

66. Polazzi E, Altamira LE, Eleuteri S, et al. Neuroprotection of microglial conditioned medium on 6-hydroxydopamine-induced neuronal death: role of transforming growth factor $\beta$-2. J Neurochem 2009;110:545-556.

67. Lai AY, Todd KG. Differential regulation of trophic and proinflammatory microglial effectors is dependent on severity of neuronal injury. Glia 2008;56:259-270.

68. Pinteaux E, Rothwell NJ, Boutin H. Neuroprotective actions of endogenous interleukin-1 receptor antagonist (IL-1ra) are mediated by glia. Glia 2006;53:551-556.

69. Roy A, Liu X, Pahan K. Myelin basic protein-primed T cells induce neurotrophins in glial cells via $\alpha \mathrm{v} \beta 3$ [corrected] integrin [Erratum in: J Biol Chem 2008;283:3688]. J Biol Chem 2007; 282:32222-32232.

70. Bai B, Song W, Ji Y, et al. Microglia and microglia-like cell differentiated from DC inhibit CD4 T cell proliferation. PLoS One 2009;4:e7869.

71. Neumann J, Sauerzweig S, Rönicke R, et al. Microglia cells protect neurons by direct engulfment of invading neutrophil granulocytes: a new mechanism of CNS immune privilege. J Neurosci 2008;28:5965-5975.

72. Bao F, Dekaban GA, Weaver LC. Anti-CD11d antibody treatment reduces free radical formation and cell death in the injured spinal cord of rats. J Neurochem 2005;94:1361-1373.

73. Hausmann ON. Post-traumatic inflammation following spinal cord injury. Spinal Cord 2003;41:369-378.

74. Fitch MT, Doller C, Combs CK, Landreth GE, Silver J. Cellular and molecular mechanisms of glial scarring and progressive cavitation: in vivo and in vitro analysis of inflammation-induced 
secondary injury after CNS trauma. J Neurosci 1999;19:81828198.

75. Dusart I, Schwab ME. Secondary cell death and the inflammatory reaction after dorsal hemisection of the rat spinal cord. Eur J Neurosci 1994;6:712-724.

76. Koshinaga M, Whittemore SR. The temporal and spatial activation of microglia in fiber tracts undergoing anterograde and retrograde degeneration following spinal cord lesion. J Neurotrauma 1995;12:209-222.

77. Bareyre FM, Schwab ME. Inflammation, degeneration and regeneration in the injured spinal cord: insights from DNA microarrays. Trends Neurosci 2003;26:555-563.

78. Popovich PG, Guan Z, McGaughy V, Fisher L, Hickey WF, Basso DM. The neuropathological and behavioral consequences of intraspinal microglial/macrophage activation. J Neuropathol Exp Neurol 2002;61:623-633.

79. Keane RW, Davis AR, Dietrich WD. Inflammatory and apoptotic signaling after spinal cord injury. J Neurotrauma 2006;23:335344.

80. Wang X, Arcuino G, Takano T, et al. P2X7 receptor inhibition improves recovery after spinal cord injury. Nat Med 2004;10: 821-827.

81. Schwab JM, Brechtel K, Nguyen TD, Schluesener HJ. Persistent accumulation of cyclooxygenase-1 (COX-1) expressing microglia/macrophages and upregulation by endothelium following spinal cord injury. J Neuroimmunol 2000;111:122-130.

82. Schmitt AB, Buss A, Breuer S, et al. Major histocompatibility complex class II expression by activated microglia caudal to lesions of descending tracts in the human spinal cord is not associated with a T cell response. Acta Neuropathol 2000;100: $528-536$.

83. Popovich PG, van Rooijen N, Hickey WF, Preidis G, McGaughy V. Hematogenous macrophages express CD8 and distribute to regions of lesion cavitation after spinal cord injury. Exp Neurol 2003;182:275-287.

84. Bruce-Keller AJ. Microglial-neuronal interactions in synaptic damage and recovery. J Neurosci Res 1999;58:191-201.

85. Aggarwal BB, Samanta A, Feldman M. TNF $\alpha$. In: Oppenheim JJ, Feldman M, editors. Cytokine reference: a compendium of cytokines and other mediators of host defense. San Diego: Academic Press, 2001:413-434.

86. Benveniste EN. Inflammatory cytokines within the central nervous system: sources, function, and mechanism of action. Am J Physiol 1992;263:C1-C16.

87. Bartholdi D, Schwab ME. Expression of pro-inflammatory cytokine and chemokine mRNA upon experimental spinal cord injury in mouse: an in situ hybridization study. Eur J Neurosci 1997;9: 1422-1438.

88. Hayashi M, Ueyama T, Nemoto K, Tamaki T, Senba E. Sequential mRNA expression for immediate early genes, cytokines, and neurotrophins in spinal cord injury. J Neurotrauma 2000;17:203-218.

89. Streit WJ, Semple-Rowland SL, Hurley SD, Miller RC, Popovich PG, Stokes BT. Cytokine mRNA profiles in contused spinal cord and axotomized facial nucleus suggest a beneficial role for inflammation and gliosis. Exp Neurol 1998;152:74-87.

90. Li JM, Fan LM, Christie MR, Shah AM. Acute tumor necrosis factor $\alpha$ signaling via NADPH oxidase in microvascular endothelial cells: role of $\mathrm{p} 47^{\text {phox }}$ phosphorylation and binding to TRAF4. Mol Cell Biol 2005;25:2320-2330.

91. Zou JY, Crews FT. TNF $\alpha$ potentiates glutamate neurotoxicity by inhibiting glutamate uptake in organotypic brain slice cultures: neuroprotection by $\mathrm{NF} \kappa \mathrm{B}$ inhibition. Brain Res 2005;1034: $11-24$.

92. Di Giovanni S, Knoblach SM, Brandoli C, Aden SA, Hoffman EP, Faden AI. Gene profiling in spinal cord injury shows role of cell cycle in neuronal death. Ann Neurol 2003;53:454-468.

93. De Biase A, Knoblach SM, Di Giovanni S, et al. Gene expression profiling of experimental traumatic spinal cord injury as a function of distance from impact site and injury severity. Physiol Genomics 2005;22:368-381.

94. Aimone JB, Leasure JL, Perreau VM, Thallmair M. Spatial and temporal gene expression profiling of the contused rat spinal cord. Exp Neurol 2004;189:204-221.
95. Carmel JB, Galante A, Soteropoulos P, et al. Gene expression profiling of acute spinal cord injury reveals spreading inflammatory signals and neuron loss. Physiol Genomics 2001;7:201-213.

96. Byrnes KR, Garay J, Di Giovanni S, et al. Expression of two temporally distinct microglia-related gene clusters after spinal cord injury. Glia 2006;53:420-433.

97. Zai LJ, Wrathall JR. Cell proliferation and replacement following contusive spinal cord injury. Glia 2005;50:247-257.

98. Carlson SL, Parrish ME, Springer JE, Doty K, Dossett L. Acute inflammatory response in spinal cord following impact injury. Exp Neurol 1998;151:77-88.

99. Popovich PG, Wei P, Stokes BT. Cellular inflammatory response after spinal cord injury in Sprague-Dawley and Lewis rats. J Comp Neurol 1997;377:443-464.

100. Beck KD, Nguyen HX, Galvan MD, Salazar DL, Woodruff TM, Anderson AJ. Quantitative analysis of cellular inflammation after traumatic spinal cord injury: evidence for a multiphasic inflammatory response in the acute to chronic environment. Brain 2010; 133:433-447.

101. Aloisi F. Immune function of microglia. Glia 2001;36:165-179.

102. Popovich PG, Hickey WF. Bone marrow chimeric rats reveal the unique distribution of resident and recruited macrophages in the contused rat spinal cord. J Neuropathol Exp Neurol 2001;60:676685 .

103. Yang L, Jones NR, Blumbergs PC, et al. Severity-dependent expression of pro-inflammatory cytokines in traumatic spinal cord injury in the rat. J Clin Neurosci 2005;12:276-284.

104. Popovich PG, Horner PJ, Mullin BB, Stokes BT. A quantitative spatial analysis of the blood-spinal cord barrier: I. Permeability changes after experimental spinal contusion injury. Exp Neurol 1996;142:258-275.

105. Shechter R, London A, Varol C, et al. Infiltrating blood-derived macrophages are vital cells playing an anti-inflammatory role in recovery from spinal cord injury in mice. PLoS Med 2009;6: e1000113.

106. Vaziri ND, Lee YS, Lin CY, Lin VW, Sindhu RK. NAD(P)H oxidase, superoxide dismutase, catalase, glutathione peroxidase and nitric oxide synthase expression in subacute spinal cord injury. Brain Res 2004;995:76-83.

107. Liu D, Bao F, Prough DS, Dewitt DS. Peroxynitrite generated at the level produced by spinal cord injury induces peroxidation of membrane phospholipids in normal rat cord: reduction by a metalloporphyrin. J Neurotrauma 2005;22:1123-1133.

108. Bao F, Liu D. Peroxynitrite generated in the rat spinal cord induces neuron death and neurological deficits. Neuroscience 2002;115:839-849.

109. Xu M, Yip GW, Gan LT, Ng YK. Distinct roles of oxidative stress and antioxidants in the nucleus dorsalis and red nucleus following spinal cord hemisection. Brain Res 2005;1055:137-142.

110. Wu J, Yoo S, Wilcock D, et al. Interaction of NG2(+) glial progenitors and microglia/macrophages from the injured spinal cord. Glia 2010;58:410-422.

111. Horn KP, Busch SA, Hawthorne AL, van Rooijen N, Silver J. Another barrier to regeneration in the CNS: activated macrophages induce extensive retraction of dystrophic axons through direct physical interactions. J Neurosci 2008;28:9330-9341.

112. Rolls A, Shechter R, London A, et al. Two faces of chondroitin sulfate proteoglycan in spinal cord repair: a role in microglia/ macrophage activation. PLoS Med 2008;5:e171.

113. Slepko N, Levi G. Progressive activation of adult microglial cells in vitro. Glia 1996;16:241-246.

114. Zhang KH, Xiao HS, Lu PH, et al. Differential gene expression after complete spinal cord transection in adult rats: an analysis focused on a subchronic post-injury stage. Neuroscience 2004 128:375-388.

115. Reichert F, Rotshenker S. Deficient activation of microglia during optic nerve degeneration. J Neuroimmunol 1996;70:153-161.

116. Povlishock JT, Katz DI. Update of neuropathology and neurological recovery after traumatic brain injury. J Head Trauma Rehabil 2005;20:76-94.

117. McIntosh TK, Saatman KE, Raghupathi R, et al. The Dorothy Russell Memorial Lecture. The molecular and cellular sequelae of 
experimental traumatic brain injury: pathogenetic mechanisms. Neuropathol Appl Neurobiol 1998;24:251-267.

118. Streit WJ. The role of microglia in brain injury. Neurotoxicology 1996; 17:671-678

119. Giordana MT, Attanasio A, Cavalla P, Migheli A, Vigliani MC, Schiffer D. Reactive cell proliferation and microglia following injury to the rat brain. Neuropathol Appl Neurobiol 1994;20:163174.

120. Haynes SE, Hollopeter G, Yang G, et al. The P2Y12 receptor regulates microglial activation by extracellular nucleotides. Nat Neurosci 2006;9:1512-1519.

121. Engel S, Schluesener H, Mittelbronn M, et al. Dynamics of microglial activation after human traumatic brain injury are revealed by delayed expression of macrophage-related proteins MRP8 and MRP14. Acta Neuropathol 2000;100:313-322.

122. Beschorner R, Nguyen TD, Gözalan F, et al. CD14 expression by activated parenchymal microglia/macrophages and infiltrating monocytes following human traumatic brain injury. Acta Neuropathol 2002;103:541-549.

123. Gentleman SM, Leclercq PD, Moyes L, et al. Long-term intracerebral inflammatory response after traumatic brain injury. Forensic Sci Int 2004;146:97-104.

124. Csuka E, Hans VH, Ammann E, Trentz O, Kossmann T, Morganti-Kossmann MC. Cell activation and inflammatory response following traumatic axonal injury in the rat. Neuroreport 2000;11:2587-2590.

125. Maeda J, Higuchi M, Inaji M, et al. Phase-dependent roles of reactive microglia and astrocytes in nervous system injury as delineated by imaging of peripheral benzodiazepine receptor. Brain Res 2007;1157:100-111.

126. Raghavendra Rao VL, Dogan A, Bowen KK, Dempsey RJ. Traumatic brain injury leads to increased expression of peripheral-type benzodiazepine receptors, neuronal death, and activation of astrocytes and microglia in rat thalamus. Exp Neurol 2000;161: 102-114.

127. Raghavendra Rao VL, Dhodda VK, Song G, Bowen KK, Dempsey RJ. Traumatic brain injury-induced acute gene expression changes in rat cerebral cortex identified by GeneChip analysis. J Neurosci Res 2003;71:208-219.

128. Natale JE, Ahmed F, Cernak I, Stoica B, Faden AI. Gene expression profile changes are commonly modulated across models and species after traumatic brain injury. J Neurotrauma 2003;20:907927.

129. Kobori N, Clifton GL, Dash P. Altered expression of novel genes in the cerebral cortex following experimental brain injury. Brain Res Mol Brain Res 2002;104:148-158.

130. Israelsson C, Bengtsson H, Kylberg A, et al. Distinct cellular patterns of upregulated chemokine expression supporting a prominent inflammatory role in traumatic brain injury. J Neurotrauma 2008;25:959-974.

131. Lu KT, Wang YW, Yang JT, Yang YL, Chen HI. Effect of interleukin-1 on traumatic brain injury-induced damage to hippocampal neurons [Erratum in: J Neurotrauma 2009;26:469]. J Neurotrauma 2005;22:885-895.

132. Lu KT, Wang YW, Wo YY, Yang YL. Extracellular signalregulated kinase-mediated IL-1-induced cortical neuron damage during traumatic brain injury. Neurosci Lett 2005;386:40-45.

133. Fan L, Young PR, Barone FC, Feuerstein GZ, Smith DH, McIntosh TK. Experimental brain injury induces expression of interleukin- $\beta$ mRNA in the rat brain. Brain Res Mol Brain Res 1995;30:125-130.

134. Pinteaux E, Parker LC, Rothwell NJ, Luheshi GN. Expression of interleukin-1 receptors and their role in interleukin-1 actions in murine microglial cells. J Neurochem 2002;83:754-763.

135. Rothwell N. Interleukin-1 and neuronal injury: mechanisms, modification, and therapeutic potential. Brain Behav Immun 2003; 17:152-157.

136. Toulmond S, Rothwell NJ. Interleukin-1 receptor antagonist inhibits neuronal damage caused by fluid percussion injury in the rat. Brain Res 1995;671:261-266.

137. Tehranian R, Andell-Jonsson S, Beni SM, et al. Improved recovery and delayed cytokine induction after closed head injury in mice with central overexpression of the secreted isoform of the interleukin-1 receptor antagonist. J Neurotrauma 2002;19:939-951.

138. Basu A, Krady JK, O’Malley M, Styren SD, DeKosky ST, Levison SW. The type 1 interleukin-1 receptor is essential for the efficient activation of microglia and the induction of multiple proinflammatory mediators in response to brain injury. J Neurosci 2002;22:6071-6082.

139. Ross SA, Halliday MI, Campbell GC, Byrnes DP, Rowlands BJ. The presence of tumour necrosis factor in CSF and plasma after severe head injury. Br J Neurosurg 1994;8:419-425.

140. Goodman JC, Robertson CS, Grossman RG, Narayan RK. Elevation of tumor necrosis factor in head injury. J Neuroimmunol 1990;30:213-217.

141. Stover JF, Schöning B, Beyer TF, Woiciechowsky C, Unterberg AW. Temporal profile of cerebrospinal fluid glutamate, interleukin-6, and tumor necrosis factor- $\alpha$ in relation to brain edema and contusion following controlled cortical impact injury in rats. Neurosci Lett 2000;288:25-28.

142. Shohami E, Novikov M, Bass R, Yamin A, Gallily R. Closed head injury triggers early production of TNF $\alpha$ and IL- 6 by brain tissue. J Cereb Blood Flow Metab 1994;14:615-619.

143. Fan L, Young PR, Barone FC, Feuerstein GZ, Smith DH, McIntosh TK. Experimental brain injury induces differential expression of tumor necrosis factor- $\alpha$ mRNA in the CNS. Brain Res Mol Brain Res 1996;36:287-291.

144. Sullivan PG, Bruce-Keller AJ, Rabchevsky AG, et al. Exacerbation of damage and altered NF- $\kappa \mathrm{B}$ activation in mice lacking tumor necrosis factor receptors after traumatic brain injury. J Neurosci 1999;19:6248-6256.

145. Scherbel U, Raghupathi R, Nakamura M, et al. Differential acute and chronic responses of tumor necrosis factor-deficient mice to experimental brain injury. Proc Natl Acad Sci U S A 1999;96: $8721-8726$

146. Morganti-Kossmann MC, Hans VH, Lenzlinger PM, et al. TGF- $\beta$ is elevated in the CSF of patients with severe traumatic brain injuries and parallels blood-brain barrier function. J Neurotrauma 1999; 16:617-628.

147. Csuka E, Morganti-Kossmann MC, Lenzlinger PM, Joller H, Trentz O, Kossmann T. IL-10 levels in cerebrospinal fluid and serum of patients with severe traumatic brain injury: relationship to IL-6, TNF- $\alpha$, TGF- $\beta 1$ and blood-brain barrier function. J Neuroimmunol 1999;101:211-221.

148. Knoblach SM, Faden AI. Interleukin-10 improves outcome and alters proinflammatory cytokine expression after experimental traumatic brain injury. Exp Neurol 1998;153:143-151.

149. Kremlev SG, Palmer C. Interleukin-10 inhibits endotoxin-induced pro-inflammatory cytokines in microglial cell cultures. J Neuroimmunol 2005;162:71-80.

150. Tyor WR, Avgeropoulos N, Ohlandt G, Hogan EL. Treatment of spinal cord impact injury in the rat with transforming growth factor- $\beta$. J Neurol Sci 2002;200:33-41.

151. Hamada $\mathrm{Y}$, Ikata $\mathrm{T}$, Katoh $\mathrm{S}$, et al. Effects of exogenous transforming growth factor- $\beta 1$ on spinal cord injury in rats. Neurosci Lett 1996;203:97-100.

152. Lucin KM, Wyss-Coray T. Immune activation in brain aging and neurodegeneration: too much or too little? Neuron 2009;64:110_ 122.

153. Galbraith S. Head injuries in the elderly. Br Med J (Clin Res Ed) 1987;294:325

154. Pennings JL, Bachulis BL, Simons CT, Slazinski T. Survival after severe brain injury in the aged. Arch Surg 1993;128:787-793; discussion 793-784.

155. Sandhir R, Onyszchuk G, Berman NE. Exacerbated glial response in the aged mouse hippocampus following controlled cortical impact injury. Exp Neurol 2008;213:372-380.

156. Conde JR, Streit WJ. Effect of aging on the microglial response to peripheral nerve injury. Neurobiol Aging 2006;27:1451-1461.

157. Popa-Wagner A, Carmichael ST, Kokaia Z, Kessler C, Walker LC. The response of the aged brain to stroke: too much, too soon? Curr Neurovasc Res 2007;4:216-227.

158. Graves AB, White E, Koepsell TD, et al. The association between head trauma and Alzheimer's disease. Am J Epidemiol 1990;131: 491-501. 
159. Mortimer JA, French LR, Hutton JT, Schuman LM. Head injury as a risk factor for Alzheimer's disease. Neurology 1985;35:264267.

160. van Duijn CM, Tanja TA, Haaxma R, et al. Head trauma and the risk of Alzheimer's disease. Am J Epidemiol 1992;135:775-782.

161. Ikonomovic MD, Uryu K, Abrahamson EE, et al. Alzheimer's pathology in human temporal cortex surgically excised after severe brain injury. Exp Neurol 2004;190:192-203.

162. Roberts GW, Gentleman SM, Lynch A, Graham DI. $\beta$ A4 amyloid protein deposition in brain after head trauma. Lancet 1991; 338:1422-1423.

163. Roberts GW, Gentleman SM, Lynch A, Murray L, Landon M, Graham DI. $\beta$ amyloid protein deposition in the brain after severe head injury: implications for the pathogenesis of Alzheimer's disease. J Neurol Neurosurg Psychiatry 1994;57:419-425.

164. Johnson VE, Stewart W, Smith DH. Traumatic brain injury and amyloid- $\beta$ pathology: a link to Alzheimer's disease? Nat Rev Neurosci 2010;11:361-370.

165. Yankner BA, Dawes LR, Fisher S, Villa-Komaroff L, OsterGranite ML, Neve RL. Neurotoxicity of a fragment of the amyloid precursor associated with Alzheimer's disease. Science 1989; 245:417-420.

166. Cagnin A, Brooks DJ, Kennedy AM, et al. In-vivo measurement of activated microglia in dementia [Erratum in: Lancet 2001;358: 766]. Lancet 2001;358:461-467.

167. McGeer PL, Itagaki S, Tago H, McGeer EG. Reactive microglia in patients with senile dementia of the Alzheimer type are positive for the histocompatibility glycoprotein HLA-DR. Neurosci Lett 1987;79:195-200.

168. Ii M, Sunamoto M, Ohnishi K, Ichimori Y. $\beta$-Amyloid proteindependent nitric oxide production from microglial cells and neurotoxicity. Brain Res 1996;720:93-100.

169. Holmin S, Mathiesen T. Long-term intracerebral inflammatory response after experimental focal brain injury in rat. Neuroreport 1999;10:1889-1891.

170. Yrjänheikki J, Keinänen R, Pellikka M, Hökfelt T, Koistinaho J. Tetracyclines inhibit microglial activation and are neuroprotective in global brain ischemia. Proc Natl Acad Sci U S A 1998; 95:15769-15774.

171. Tikka T, Fiebich BL, Goldsteins G, Keinanen R, Koistinaho J. Minocycline, a tetracycline derivative, is neuroprotective against excitotoxicity by inhibiting activation and proliferation of microglia. J Neurosci 2001;21:2580-2588.

172. Kremlev SG, Roberts RL, Palmer C. Differential expression of chemokines and chemokine receptors during microglial activation and inhibition. J Neuroimmunol 2004;149:1-9.

173. Choi SH, Lee DY, Chung ES, Hong YB, Kim SU, Jin BK. Inhibition of thrombin-induced microglial activation and NADPH oxidase by minocycline protects dopaminergic neurons in the substantia nigra in vivo. J Neurochem 2005;95: $1755-1765$.

174. Seabrook TJ, Jiang L, Maier M, Lemere CA. Minocycline affects microglia activation, $\mathrm{A} \beta$ deposition, and behavior in APP-tg mice. Glia 2006;53:776-782.

175. Sanchez Mejia RO, Ona VO, Li M, Friedlander RM. Minocycline reduces traumatic brain injury-mediated caspase-1 activation, tissue damage, and neurological dysfunction. Neurosurgery 2001; 48:1393-1399; discussion 1399-1401.

176. Lee SM, Yune TY, Kim SJ, et al. Minocycline reduces cell death and improves functional recovery after traumatic spinal cord injury in the rat. J Neurotrauma 2003;20:1017-1027.

177. Wells JE, Hurlbert RJ, Fehlings MG, Yong VW. Neuroprotection by minocycline facilitates significant recovery from spinal cord injury in mice. Brain 2003;126:1628-1637.

178. Stirling DP, Khodarahmi K, Liu J, et al. Minocycline treatment reduces delayed oligodendrocyte death, attenuates axonal dieback, and improves functional outcome after spinal cord injury. J Neurosci 2004;24:2182-2190.

179. Teng YD, Choi H, Onario RC, et al. Minocycline inhibits contusion-triggered mitochondrial cytochrome $\mathrm{c}$ release and miti- gates functional deficits after spinal cord injury. Proc Natl Acad Sci U S A 2004;101:3071-3076.

180. Yune TY, Lee JY, Jung GY, et al. Minocycline alleviates death of oligodendrocytes by inhibiting pro-nerve growth factor production in microglia after spinal cord injury. J Neurosci 2007;27: $7751-7761$.

181. Festoff BW, Ameenuddin S, Arnold PM, Wong A, Santacruz KS, Citron BA. Minocycline neuroprotects, reduces microgliosis, and inhibits caspase protease expression early after spinal cord injury. J Neurochem 2006;97:1314-1326.

182. Berger J, Moller DE. The mechanisms of action of PPARs. Annu Rev Med 2002;53:409-435.

183. Chawla A, Barak Y, Nagy L, Liao D, Tontonoz P, Evans RM. PPAR- $\gamma$ dependent and independent effects on macrophage-gene expression in lipid metabolism and inflammation. Nat Med 2001; 7:48-52.

184. Pereira MP, Hurtado O, Cárdenas A, et al. Rosiglitazone and 15-deoxy- $\Delta^{12,14}$-prostaglandin $\mathrm{J}_{2}$ cause potent neuroprotection after experimental stroke through noncompletely overlapping mechanisms. J Cereb Blood Flow Metab 2006;26:218-229.

185. Sundararajan S, Gamboa JL, Victor NA, Wanderi EW, Lust WD, Landreth GE. Peroxisome proliferator-activated receptor- $\gamma$ ligands reduce inflammation and infarction size in transient focal ischemia. Neuroscience 2005;130:685-696.

186. Park SW, Yi JH, Miranpuri G, et al. Thiazolidinedione class of peroxisome proliferator-activated receptor $\gamma$ agonists prevents neuronal damage, motor dysfunction, myelin loss, neuropathic pain, and inflammation after spinal cord injury in adult rats. J Pharmacol Exp Ther 2007;320:1002-1012.

187. Collino M, Aragno M, Mastrocola R, et al. Modulation of the oxidative stress and inflammatory response by PPAR- $\gamma$ agonists in the hippocampus of rats exposed to cerebral ischemia/reperfusion. Eur J Pharmacol 2006;530:70-80.

188. Bernardo A, Minghetti L. PPAR- $\gamma$ agonists as regulators of microglial activation and brain inflammation. Curr Pharm Des 2006; 12:93-109.

189. Bethea JR, Nagashima H, Acosta MC, et al. Systemically administered interleukin-10 reduces tumor necrosis factor- $\alpha$ production and significantly improves functional recovery following traumatic spinal cord injury in rats. J Neurotrauma 1999;16:851-863.

190. Morganti-Kossmann MC, Rancan M, Stahel PF, Kossmann T. Inflammatory response in acute traumatic brain injury: a doubleedged sword. Curr Opin Crit Care 2002;8:101-105.

191. Lenzlinger PM, Morganti-Kossmann MC, Laurer HL, McIntosh TK. The duality of the inflammatory response to traumatic brain injury. Mol Neurobiol 2001;24:169-181.

192. Tian DS, Xie MJ, Yu ZY, et al. Cell cycle inhibition attenuates microglia induced inflammatory response and alleviates neuronal cell death after spinal cord injury in rats. Brain Res 2007;1135:177_ 185.

193. Dijkstra S, Duis S, Pans IM, et al. Intraspinal administration of an antibody against CD81 enhances functional recovery and tissue sparing after experimental spinal cord injury. Exp Neurol 2006; 202:57-66.

194. Gadient RA, Cron KC, Otten U. Interleukin- $1 \beta$ and tumor necrosis factor- $\alpha$ synergistically stimulate nerve growth factor (NGF) release from cultured rat astrocytes. Neurosci Lett 1990;117:335340.

195. Bouhy D, Malgrange B, Multon S, et al. Delayed GM-CSF treatment stimulates axonal regeneration and functional recovery in paraplegic rats via an increased BDNF expression by endogenous macrophages. FASEB J 2006;20:1239-1241.

196. Prewitt CM, Niesman IR, Kane CJ, Houle JD. Activated macrophage/microglial cells can promote the regeneration of sensory axons into the injured spinal cord. Exp Neurol 1997;148:433-443.

197. Stoica B, Byrnes K, Faden AI. Multifunctional drug treatment in neurotrauma. Neurotherapeutics 2009;6:14-27.

198. Byrnes KR, Loane DJ, Faden AI. Metabotropic glutamate receptors as targets for multipotential treatment of neurological disorders. Neurotherapeutics 2009;6:94-107. 